\title{
Abundance and population characteristics of the invasive sea urchin Diadema setosum (Leske, 1778) in the south Aegean Sea (eastern Mediterranean)
}

\author{
Dimitris Vafidis ${ }^{1}$, Chryssanthi Antoniadou ${ }^{2 *}$, Konstantinos Voulgaris ${ }^{1}$, Anastasios Varkoulis $^{1}$ and \\ Chrysoula Apostologamvrou ${ }^{1}$
}

\begin{abstract}
Background: The Indo-Pacific sea urchin Diadema setosum has invaded the Mediterranean Sea and has spread along many locations in the southeastern part of the basin, where established populations exist on the shallow subtidal rocky shore. Diadema setosum is a ubiquitous species, of particular ecological importance due to the high levels of grazing pressure it imposes on benthic communities. Its biology, however, is not adequately studied, especially along its introduced range of distribution. The present study examines the population status of $D$. setosum outside its native range, in the Dodecanese island complex, south Aegean Sea. Thirty-four stations located across 16 islands were surveyed by scientific SCUBA-diving (up to a depth of $10 \mathrm{~m}$ ) in December 2019 and June-July 2020. Samplings included: (i) visual census along transects to estimate relative abundance and population density, and (ii) random collection of specimens from densely populated stations to assess biometry and reproductive condition (histological examination of gonads) of D. setosum.
\end{abstract}

Results: Diadema setosum was found in 21 out of the 34 surveyed stations. The species had sparse populations of well-hidden individuals in rocky crevices, but with dense localized patches in Agathonisi, Leros, Kalymnos, Pserimos, Symi, Alimia and Chalki islands. In those seven islands, mean population density was $2.5 \pm 1.48$ individuals $\mathrm{m}^{-2}$. Diadema setosum had denser populations in shallower depths but larger dimensions in deeper; these results suggest segregated density and size patterns along a depth gradient. The size structure, according to the size frequency distribution of the test diameter, was unimodal with a fitted mode at $4.0-4.5$ and $6.5-7.0 \mathrm{~cm}$ in shallow and deep populations, respectively. The examined morphometric relationships followed negative allometry, as previously suggested for the species within its native range of distribution, and test diameter appeared to be a good predictor of biomass. Diadema setosum specimens had immature gonads in winter and mature in summer, suggesting a synchronous reproductive pattern. These results conform to previous data from temperate populations of the species.

Conclusions: Differences in local environmental conditions, e.g. hydrodynamics and habitat type, together with biotic interactions, e.g. recruitment and competition, probably shape D. setosum population in the south Aegean distributional range. The establishment of $D$. setosum has severe implications on benthic communities and local sea

\footnotetext{
*Correspondence: antonch@bio.auth.gr

${ }^{2}$ School of Biology, Department of Zoology, Aristotle University of Thessaloniki, 54124 Thessaloniki, Greece

Full list of author information is available at the end of the article
}

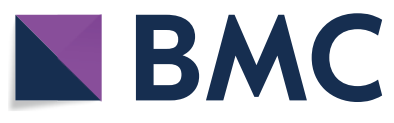

(c) The Author(s) 2021. This article is licensed under a Creative Commons Attribution 4.0 International License, which permits use, sharing, adaptation, distribution and reproduction in any medium or format, as long as you give appropriate credit to the original author(s) and the source, provide a link to the Creative Commons licence, and indicate if changes were made. The images or other third party material in this article are included in the article's Creative Commons licence, unless indicated otherwise in a credit line to the material. If material is not included in the article's Creative Commons licence and your intended use is not permitted by statutory regulation or exceeds the permitted use, you will need to obtain permission directly from the copyright holder. To view a copy of this licence, visit http://creativeco mmons.org/licenses/by/4.0/. The Creative Commons Public Domain Dedication waiver (http://creativecommons.org/publicdomain/ zero/1.0/) applies to the data made available in this article, unless otherwise stated in a credit line to the data. 
urchin populations demanding management measures to prevent the forecasted further expansion of this invasive species.

Keywords: Density, Population structure, Biometry, Aegean sea, Invasive species, Diadema

\section{Background}

Diadema is a widespread and ecologically important genus of tropical sea urchins that contains nine extant species [1]. Among these species, D. setosum (Leske, 1778) has invaded into the Mediterranean basin in 2006 [2], and, currently, is among the established non-indigenous species (NIS) of the basin [3]. It is a sea urchin of Indo-Pacific origin; its native range extends from the mid Pacific to the East African coasts [4], including the Red Sea. It is especially abundant in the northern part of the Gulf of Suez [2]. Two separate clades of D. setosum have been recognized by molecular analyses, differing in their geographic distribution: clade A spreading throughout the Indo-West Pacific and clade $B$ restricted around the Arabian Peninsula [4] and invaded the Mediterranean through the Suez Canal [5].

Diadema setosum inhabits the shallow sublittoral zone at depths ranging from one to $20 \mathrm{~m}$, but most often the species aggregates around 4-6 $\mathrm{m}$ depth. It prefers rocky habitats and biogenic reefs, where it is hiding in crevices and under overhangs-especially during intense lighting-though, it can also be found on sandy bottoms and seagrass meadows [1]. The average size of the species is $6-7 \mathrm{~cm}$ and $3.5-4 \mathrm{~cm}$ in test diameter and height, respectively. The life span of $D$. setosum is around 3.5 years, with mature specimens weighting between 35 and $80 \mathrm{~g}$ [6]. The species exhibits variable reproductive patterns in different geographic areas, influenced by local environmental factors, such as temperature, lunar patterns and conspecifics and adults' densities. Diadema setosum is an epibenthic grazer of particular ecological importance due to the high levels of grazing pressure it imposes on benthic communities. Under high densities, the species may transform rocky shores to barrens [1] and severely bioerode biogenic substrates, especially coral reefs [7]. Therefore, the population characteristics of this keystone sea urchin species may have profound cascade effects on the coastal ecosystem.

Recently, Muthiga and McClanahan [1] reviewed the biology of the genus Diadema covering several aspects, such as species evolution and biogeography, reproductive biology and recruitment, feeding ecology and grazing effects, growth and longevity, population dynamics, and community ecology and coexistence. This effort revealed that, as opposed to its congeners $D$. antillarum and $D$. mexicanum, the biology of $D$. setosum is poorly studied, and is mostly confined to tropical populations, despite being very common in many areas of its distribution. The few existing data from temperate populations are limited to the reproductive biology of the species [8-11], their grazing [12] and the bioerosive pressure they inflict in rocky biogenic habitats [13], and to the cytotoxicity of its bioactive compounds [14]. Focusing on the Mediterranean population, existing data refer exclusively to its occurrence [2, 15-26], whereas only a single study examined the genetic profile of the species and suggests further spread of D. setosum in the near future through larval transport [5].

Consequently, the present work aims to assess the current status of $D$. setosum in the Dodecanese complex (south Aegean Sea) by implementing a combination of non-destructive sampling techniques and random collection of specimens to gather information on density and biometry at spatial scales. Moreover, attempts to describe the reproductive status of the sea urchin in densely populated areas.

\section{Results}

Diadema setosum was recorded at 21 out of the 34 surveyed stations dispersed on 16 islands (Fig. 1). It settled mainly on rocky substrates along the shoreline, from 3 to $8 \mathrm{~m}$ depth, surrounded by boulders, detritic sediments and/or Posidonia oceanica meadows (Table 1). According to the applied ACFOR scale of relative abundance (see "Methods" section for numeric definition of relative abundance scale), D. setosum was present in five stations, had sparse populations in eight, and dense populations in another eight of the surveyed stations. This allowed a more accurate estimation of density in those latter eight stations, located in seven islands. Accordingly, the population density of D. setosum ranged from 0.8 to 5.3 individuals $\mathrm{m}^{-2}$ with an overall mean $(\mathrm{x} \pm \mathrm{sd})$ of $2.50 \pm 1.48$ individuals $\mathrm{m}^{-2}$. Mean density showed significant variation among islands $(\mathrm{F}=10.90, p<0.01)$ and depth zones $(\mathrm{F}=26.17, p<0.01)$. Increased densities were recorded in the shallower depth zone, and in five stations (K1, S1, S2, $\mathrm{A} 1$, and $\mathrm{C} 1$, see Table 1), located in the islands of Kalymnos, Symi, Alimia and Chalki (Fig. 2).

Overall, 160 individuals were measured to describe the size structure of the studied population: 120 from the shallower depth zone and only 40 from the deeper one. Their size ranged from 0.95 to $4.78 \mathrm{~cm}$ in height, and from 1.94 to $8.90 \mathrm{~cm}$ in diameter, with a mean $(\mathrm{x} \pm \mathrm{sd})$ of $2.61 \pm 1.04 \mathrm{~cm}(\mathrm{Ht}), 5.03 \pm 1.76 \mathrm{~cm}(\mathrm{Dt})$, respectively. 


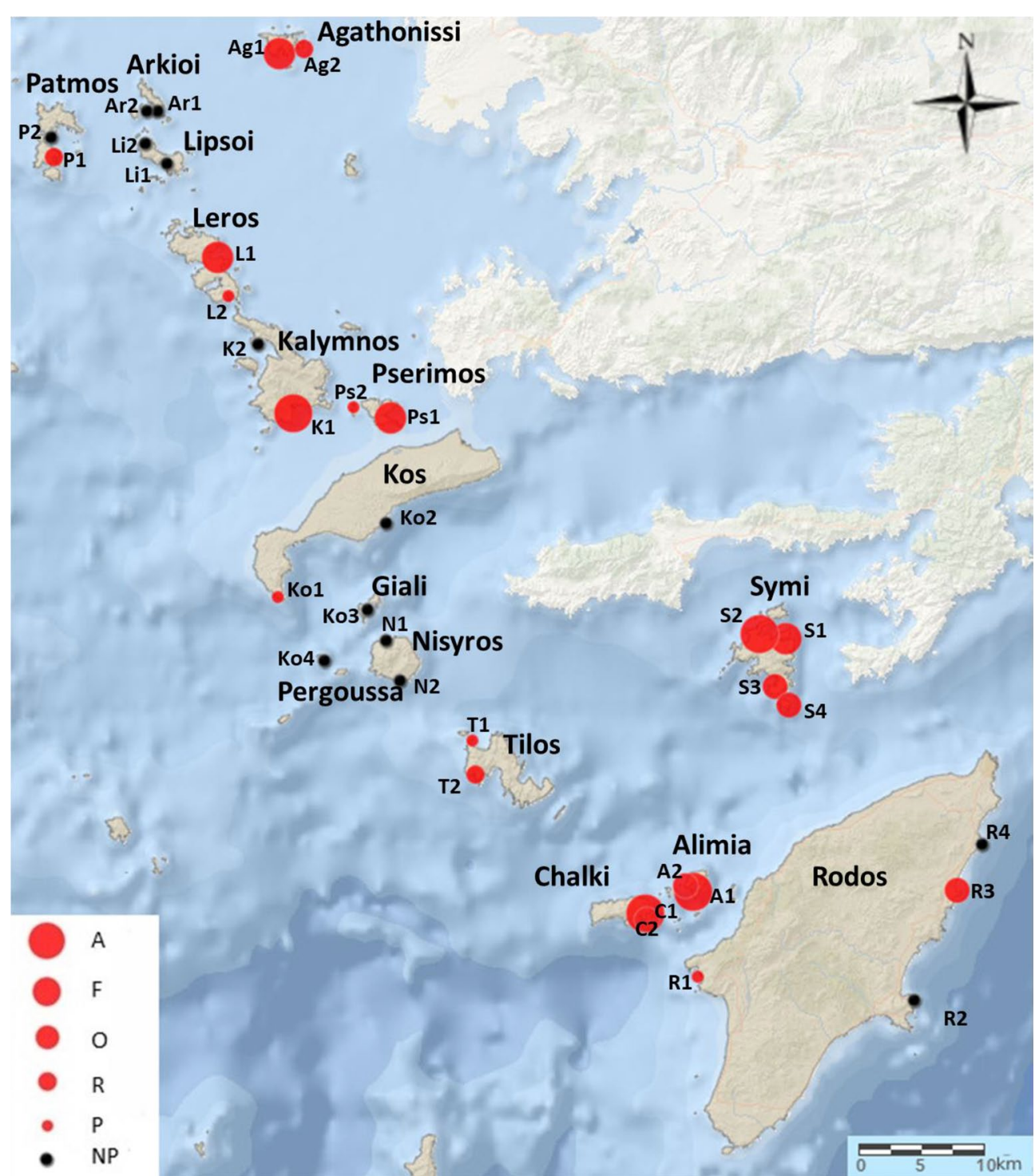

Fig. 1 Sampling stations and relative abundance of Diadema setosum in the marine area of the Dodecanese island complex. $A$ abundant, $F$ frequent, $O$ occasional, $R$ rare, $P$ present, NP no present

Their biomass ranged from 3.77 to $248.95 \mathrm{~g}$ in weight with a mean $(\mathrm{x} \pm \mathrm{sd})$ of $60.64 \pm 48.74 \mathrm{~g}(\mathrm{tW})$. Mean size and weight showed significant spatial differences between the surveyed islands (ANOVA, see Table 2).

Largest $\mathrm{Dt}, \mathrm{Ht}$ and $\mathrm{tW}$ values were recorded in the stations of Symi and Chalki islands, intermediate in Agathonisi, Kalymnos, Leros and Pserimos, and decreased in Alimia (Fig. 3). Differences along the depth gradient were even more pronounce, with significantly increased values in deeper populations (Fig. 3). According to ANOVA and Fisher LSD post-hoc comparisons of $D$. setosum biometric features at each depth zone separately, the sea urchin had significantly $(p<0.001)$ larger dimensions $(\mathrm{Dt}, \mathrm{Ht})$ and weight (tW) in Symi, Pserimos and Kalymnos, and smaller in Alimia, Chalki and Leros in the shallow depth zone (Fig. 4, left graph). In the deeper depth zone, significantly larger urchins were measured (for $\mathrm{Dt}$ and $\mathrm{Ht}$ ) in Symi and Chalki, and heavier urchins in Symi (ANOVA, $p<0.001$; Fig. 4, right graph).

Based on the above results, size frequency distributions (SFD) were calculated for each depth zone, and island separately. Overall, the studied populations were normally distributed with a fitted mode at 4.0-4.5 and 6.5$7.0 \mathrm{~cm} \mathrm{Dt}$ in the shallow and deeper zones, respectively (Fig. 5). By focusing to the shallower depth zone, the lowest SFD mode was at $3.0-3.5 \mathrm{~cm}$ in Alimia and the largest 
Table 1 Location, code and geomorphological characteristics [depth, substrate type ( $R=$ rocky, $B=$ boulders, $D=$ detritic, $\mathrm{M}=$ meadows), slope $(\mathrm{H}=$ horizontal, $\mathrm{Ml}=$ moderately inclined, $\mathrm{I}=$ inclined)] of the surveyed stations in the Dodecanese island complex (south Aegean Sea)

\begin{tabular}{|c|c|c|c|c|c|c|c|c|c|}
\hline Island & Toponym & Latitude/Longitude & Code & Date & $\begin{array}{l}\text { Depth } \\
\text { (m) }\end{array}$ & $\begin{array}{l}\text { Substrata } \\
\text { Type/Slope }\end{array}$ & Method & $\begin{array}{l}\text { Relative } \\
\text { abundance }\end{array}$ & $\begin{array}{l}\text { Density } \\
\mathrm{N} \mathrm{m}^{-2}\end{array}$ \\
\hline \multirow[t]{2}{*}{ Patmos } & Grikou & $37^{\circ} 18^{\prime} 02.3^{\prime \prime} \mathrm{N} 26^{\circ} 33^{\prime} 49.7^{\prime \prime} \mathrm{E}$ & P1 & $12 / 19$ & $3-5$ & $\mathrm{R} / \mathrm{Ml}$ & $\mathrm{T}_{500}$ & $\mathrm{R}$ & \\
\hline & Meloi & $37^{\circ} 19^{\prime} 47.2^{\prime \prime} \mathrm{N} 26^{\circ} 35^{\prime} 04.5^{\prime \prime} \mathrm{E}$ & P2 & $12 / 19$ & $<10$ & $\mathrm{DM} / \mathrm{H}$ & $\mathrm{T}_{500}$ & NP & \\
\hline \multirow[t]{2}{*}{ Agathonisi } & A.Georgios & $37^{\circ} 27^{\prime} 03.4^{\prime \prime} \mathrm{N} 26^{\circ} 59^{\prime} 15.1^{\prime \prime} \mathrm{E}$ & $\mathrm{Ag} 1$ & $12 / 19$ & $3-6$ & R/MI & $\mathrm{T}_{500} / \mathrm{T}_{10}$ & $F$ & $1.2 \pm 6.8$ \\
\hline & A.Nikolaos & $37^{\circ} 27^{\prime} 27.3^{\prime \prime} \mathrm{N} 26^{\circ} 59^{\prime} 39.1^{\prime \prime} \mathrm{E}$ & $\mathrm{Ag} 2$ & $12 / 19$ & $3-6$ & $\mathrm{R} / \mathrm{Ml}$ & $T_{500}$ & $\mathrm{R}$ & \\
\hline \multirow[t]{2}{*}{ Arkioi } & Tiganaki & $37^{\circ} 22^{\prime} 01.8^{\prime \prime} \mathrm{N} 26^{\circ} 44^{\prime} 49.3^{\prime \prime} \mathrm{E}$ & $\operatorname{Ar} 1$ & $12 / 19$ & $<10$ & $\mathrm{R} / \mathrm{Ml}$ & $\mathrm{T}_{500}$ & NP & \\
\hline & Marathi & $37^{\circ} 21^{\prime} 59.7^{\prime \prime} \mathrm{N} 26^{\circ} 43^{\prime} 38.0^{\prime \prime} \mathrm{E}$ & Ar2 & $12 / 19$ & $<10$ & $\mathrm{RbM} / \mathrm{Ml}$ & $\mathrm{T}_{500}$ & NP & \\
\hline \multirow[t]{2}{*}{ Lipsoi } & Moshato & $37^{\circ} 19^{\prime} 17.8^{\prime \prime} \mathrm{N} 26^{\circ} 43^{\prime} 22.2^{\prime \prime} \mathrm{E}$ & Li1 & $12 / 19$ & $<10$ & $\mathrm{RbM} / \mathrm{Ml}$ & $T_{500}$ & NP & \\
\hline & & $37^{\circ} 17^{\prime} 34.2^{\prime \prime} \mathrm{N} 26^{\circ} 45^{\prime} 47.8^{\prime \prime} \mathrm{E}$ & Li2 & $12 / 19$ & $<10$ & $\mathrm{RbM} / \mathrm{Ml}$ & $\mathrm{T}_{500}$ & NP & \\
\hline \multirow[t]{2}{*}{ Leros } & Agia Marina & $37^{\circ} 10^{\prime} 31.4^{\prime \prime} \mathrm{N} 26^{\circ} 51^{\prime} 04.8^{\prime \prime} \mathrm{E}$ & L1 & $12 / 19$ & $4 / 8$ & $\mathrm{R} / \mathrm{H}-\mathrm{R} / \mathrm{Ml}$ & $\mathrm{T}_{500} / \mathrm{T}_{10}$ & $\mathrm{~F}$ & $1.6 \pm 8.3 / 0.8 \pm 2.2$ \\
\hline & Xirokampos & $37^{\circ} 06^{\prime} 20.7^{\prime \prime} \mathrm{N} 26^{\circ} 52^{\prime} 21.2^{\prime \prime} \mathrm{E}$ & L2 & $12 / 19$ & $4-6$ & $\mathrm{RbM} / \mathrm{Ml}$ & $\mathrm{T}_{500}$ & $P$ & \\
\hline \multirow[t]{2}{*}{ Kalymnos } & Therma & $36^{\circ} 56^{\prime} 15.5^{\prime \prime} \mathrm{N} 26^{\circ} 59^{\prime} 16.2^{\prime \prime} \mathrm{E}$ & K1 & $12 / 19$ & $4-5$ & $\mathrm{Rb} / \mathrm{H}$ & $\mathrm{T}_{500} / \mathrm{T}_{10}$ & A & $2.3 \pm 4.57$ \\
\hline & Lepto & $37^{\circ} 02^{\prime} 32.6^{\prime \prime} \mathrm{N} 26^{\circ} 55^{\prime} 36.1^{\prime \prime} \mathrm{E}$ & $\mathrm{K} 2$ & $12 / 19$ & $<10$ & $\mathrm{Rb} / \mathrm{H}$ & $\mathrm{T}_{500}$ & NP & \\
\hline \multirow[t]{2}{*}{ Pserimos } & Vathi & $36^{\circ} 55^{\prime} 52.6^{\prime \prime} \mathrm{N} 27^{\circ} 09^{\prime} 38.9^{\prime \prime} \mathrm{E}$ & Ps1 & $12 / 19$ & $3-6$ & $\mathrm{Rb} / \mathrm{Ml}$ & $\mathrm{T}_{500} / \mathrm{T}_{10}$ & $\mathrm{~F}$ & $1.8 \pm 8.46$ \\
\hline & Plati & $36^{\circ} 56^{\prime} 54.8^{\prime \prime} \mathrm{N} 27^{\circ} 05^{\prime} 32.7^{\prime \prime} \mathrm{E}$ & Ps2 & $12 / 19$ & $3-5$ & $\mathrm{Rb} / \mathrm{Ml}$ & $\mathrm{T}_{500}$ & $P$ & \\
\hline \multirow[t]{2}{*}{ Kos } & Charakas & $36^{\circ} 40^{\prime} 34.7^{\prime \prime} \mathrm{N} 26^{\circ} 57^{\prime} 35.5^{\prime \prime} \mathrm{E}$ & Ko1 & $7 / 20$ & $3-5$ & R/MI & $\mathrm{T}_{500}$ & $P$ & \\
\hline & Kardamaina & $36^{\circ} 48^{\prime} 43.4^{\prime \prime} \mathrm{N} 27^{\circ} 11^{\prime} 25.8^{\prime \prime} \mathrm{E}$ & Ko2 & $7 / 20$ & $<10$ & $\mathrm{Rb} / \mathrm{H}$ & $T_{500}$ & NP & \\
\hline Pergoussa & & $36^{\circ} 35^{\prime} 24.0^{\prime \prime} \mathrm{N} 27^{\circ} 02^{\prime} 36.4^{\prime \prime} \mathrm{E}$ & Ko3 & $7 / 20$ & $<10$ & $\mathrm{RbM} / \mathrm{Ml}$ & $T_{500}$ & NP & \\
\hline Giali & & $36^{\circ} 40^{\prime} 01.2^{\prime \prime} \mathrm{N} 26^{\circ} 08^{\prime} 21.5^{\prime \prime} \mathrm{E}$ & Ko4 & $7 / 20$ & $2-6$ & $\mathrm{Rb} / \mathrm{H}$ & $T_{500}$ & NP & \\
\hline \multirow[t]{2}{*}{ Nisyros } & Loutra & 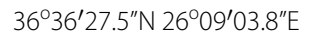 & N1 & $7 / 20$ & $<10$ & $\mathrm{Rb} / \mathrm{H}$ & $T_{500}$ & NP & \\
\hline & Avlaki & $36^{\circ} 33^{\prime} 26.7^{\prime \prime} \mathrm{N} 27^{\circ} 50^{\prime} 48.4^{\prime \prime} \mathrm{E}$ & N2 & $7 / 20$ & $<10$ & $\mathrm{RbM} / \mathrm{H}$ & $T_{500}$ & NP & \\
\hline \multirow[t]{4}{*}{ Symi } & Pedi & $36^{\circ} 36^{\prime} 59.8^{\prime \prime} \mathrm{N} 27^{\circ} 51^{\prime} 34.1^{\prime \prime} \mathrm{E}$ & S1 & $7 / 20$ & $4-6$ & $\mathrm{R} / \mathrm{I}$ & $\mathrm{T}_{500} / \mathrm{T}_{10}$ & $\mathrm{~F}$ & $2.1 \pm 3.9 / 1.3 \pm 3.5$ \\
\hline & Emporios & $36^{\circ} 37^{\prime} 54.0^{\prime \prime} \mathrm{N} 27^{\circ} 48^{\prime} 30.8^{\prime \prime} \mathrm{E}$ & S2 & $7 / 20$ & $4 / 8$ & $\mathrm{R} / \mathrm{Ml}$ & $\mathrm{T}_{500} / \mathrm{T}_{10}$ & $A$ & $4.5 \pm 6.6 / 2.6 \pm 5.1$ \\
\hline & Panormitis & $36^{\circ} 33^{\prime} 05.2^{\prime \prime} \mathrm{N} 27^{\circ} 50^{\prime} 44.1^{\prime \prime} \mathrm{E}$ & S3 & $7 / 20$ & $4-6$ & Rb-D-M/H & $\mathrm{T}_{500}$ & $\mathrm{O}$ & \\
\hline & Seskli & $36^{\circ} 32^{\prime} 43.9^{\prime \prime} \mathrm{N} 27^{\circ} 51^{\prime} 42.9^{\prime \prime} \mathrm{E}$ & S4 & $7 / 20$ & $4-6$ & $\mathrm{R} / \mathrm{Ml}$ & $T_{500}$ & $\mathrm{O}$ & \\
\hline \multirow[t]{2}{*}{ Alimia } & Tigani & $36^{\circ} 15^{\prime} 19.6^{\prime \prime} \mathrm{N} 27^{\circ} 42^{\prime} 0.66^{\prime \prime} \mathrm{E}$ & $\mathrm{A} 1$ & $7 / 20$ & $4-6$ & $\mathrm{Rb}-\mathrm{D}-\mathrm{M} / \mathrm{H}$ & $\mathrm{T}_{500} / \mathrm{T}_{10}$ & A & $4.4 \pm 8.1$ \\
\hline & & $36^{\circ} 15^{\prime} 30.6^{\prime \prime} \mathrm{N} 27^{\circ} 41^{\prime} 03.1^{\prime \prime} \mathrm{E}$ & $\mathrm{A} 2$ & $7 / 20$ & $<10$ & R-M/Ml & $\mathrm{T}_{500}$ & $\mathrm{O}$ & \\
\hline \multirow[t]{2}{*}{ Chalki } & Limani & $36^{\circ} 13^{\prime} 22.8^{\prime \prime} \mathrm{N} 27^{\circ} 36^{\prime} 47.2^{\prime \prime} \mathrm{E}$ & $\mathrm{C} 1$ & $7 / 20$ & $2-4 / 6-8$ & $\mathrm{R}-\mathrm{B}-\mathrm{M} / \mathrm{H}$ & $\mathrm{T}_{500} / \mathrm{T}_{10}$ & A & $5.3 \pm 5.9 / 2.1 \pm 4.3$ \\
\hline & Krevatia & $36^{\circ} 12^{\prime} 52.7^{\prime \prime} \mathrm{N} 27^{\circ} 37^{\prime} 09.8^{\prime \prime} \mathrm{E}$ & C2 & $7 / 20$ & $4-6$ & R-M/Ml & $\mathrm{T}_{500}$ & $\mathrm{O}$ & \\
\hline \multirow[t]{2}{*}{ Tilos } & A.Antonios & $36^{\circ} 28^{\prime} 11.2^{\prime \prime} \mathrm{N} 27^{\circ} 18^{\prime} 16.5^{\prime \prime} \mathrm{E}$ & $\mathrm{T} 1$ & $7 / 20$ & $4-6$ & R-B-M/MI & $T_{500}$ & $P$ & \\
\hline & Limenari & $36^{\circ} 25^{\prime} 24.5^{\prime \prime} \mathrm{N} 27^{\circ} 18^{\prime} 34.0^{\prime \prime} \mathrm{E}$ & $\mathrm{T} 2$ & $7 / 20$ & $4-6$ & R-M/I & $\mathrm{T}_{500}$ & R & \\
\hline \multirow[t]{4}{*}{ Rodos } & Monolithos & $36^{\circ} 08^{\prime} 51.9^{\prime \prime} \mathrm{N} 27^{\circ} 42^{\prime} 22.1^{\prime \prime} \mathrm{E}$ & R1 & $7 / 20$ & 6 & R-B-M/Ml & $\mathrm{T}_{500}$ & $P$ & \\
\hline & Lindos & $36^{\circ} 05^{\prime} 32.4^{\prime \prime} \mathrm{N} 28^{\circ} 05^{\prime} 15.6^{\prime \prime} \mathrm{E}$ & R2 & $7 / 20$ & $<10$ & $\mathrm{R}-\mathrm{B} / \mathrm{Ml}$ & $\mathrm{T}_{500}$ & NP & \\
\hline & Kolympia & $36^{\circ} 14^{\prime} 52.6^{\prime \prime} \mathrm{N} 28^{\circ} 10^{\prime} 16.7^{\prime \prime} \mathrm{E}$ & R3 & $7 / 20$ & $4-6$ & $\mathrm{R}-\mathrm{M} / \mathrm{Ml}$ & $\mathrm{T}_{500}$ & $\mathrm{O}$ & \\
\hline & Ladiko & $36^{\circ} 19^{\prime} 22.8^{\prime \prime} \mathrm{N} 28^{\circ} 12^{\prime} 43.0^{\prime \prime} \mathrm{E}$ & R4 & $7 / 20$ & $<10$ & $\mathrm{R}-\mathrm{B} / \mathrm{Ml}$ & $T_{500}$ & NP & \\
\hline
\end{tabular}

Sampling date, method $\left(T_{500}=3\right.$ transect replicates each $1 \times 500 \mathrm{~m}$ long, $T_{10}=4$ transect replicates each $1 \times 10 \mathrm{~m}$ long), relative abundance $(A=$ abundant: $>40 \%$ $\mathrm{SE}_{,}>50 \mathrm{~N}$ per $100 \mathrm{~m}^{2} ; \mathrm{C}=$ common: $20-40 \% \mathrm{SE}, 10-50 \mathrm{~N}$ per $100 \mathrm{~m}^{2} ; \mathrm{F}=$ frequent: $10-20 \% \mathrm{SE}, 5-10 \mathrm{~N}$ per $100 \mathrm{~m}^{2} ; \mathrm{O}=\mathrm{occasional}^{2} 5-10 \% \mathrm{SE}, 1-5 \mathrm{~N}$ per $100 \mathrm{~m}^{2} ; \mathrm{R}=\mathrm{rare}$ $1-5 \% \mathrm{SE},<1 \mathrm{~N}$ per $100 \mathrm{~m}^{2} ; \mathrm{P}=$ present, $\mathrm{NP}=$ no present) and population density (mean $\mathrm{N} \mathrm{m}^{-2} \pm$ standard deviation, estimated in stations with $\mathrm{A}, \mathrm{C}$ and $\mathrm{F}$ relative abundance grade) results of Diadema setosum. SE species' expansion, $N$ number of individuals

at 5.5-6.0 cm in Symi (Fig. 6, top graph). A shift towards smaller urchins in the northern (Agathonisi, Leros) and southern islands (Alimia, Chalki) may be inferred from SFD analysis. In the deeper zone, a similar south to north pattern of decreasing size was also assumed, whereas the largest mode was detected in the easternmost population of Symi island (Fig. 6 lower graph).
Biometric relationships $\mathrm{tW} / \mathrm{Dt}, \mathrm{tW} / \mathrm{Ht}, \mathrm{Ht} / \mathrm{Dt}$, estimated over the entire D. setosum population (Fig. 7) as well as per sampling depth (data not shown), were negatively correlated. The b coefficient was 2.38 for $\mathrm{tW} / \mathrm{Dt}$ ( $\mathrm{t}$-test result under the null hypothesis of $\mathrm{b}=3$ at $95 \%$ confidence level: $\mathrm{ts}=-6.45), 2.03$ for $\mathrm{tW} / \mathrm{Ht}$ (t-test results under the null hypothesis $b=3$ at $95 \%$ confidence 

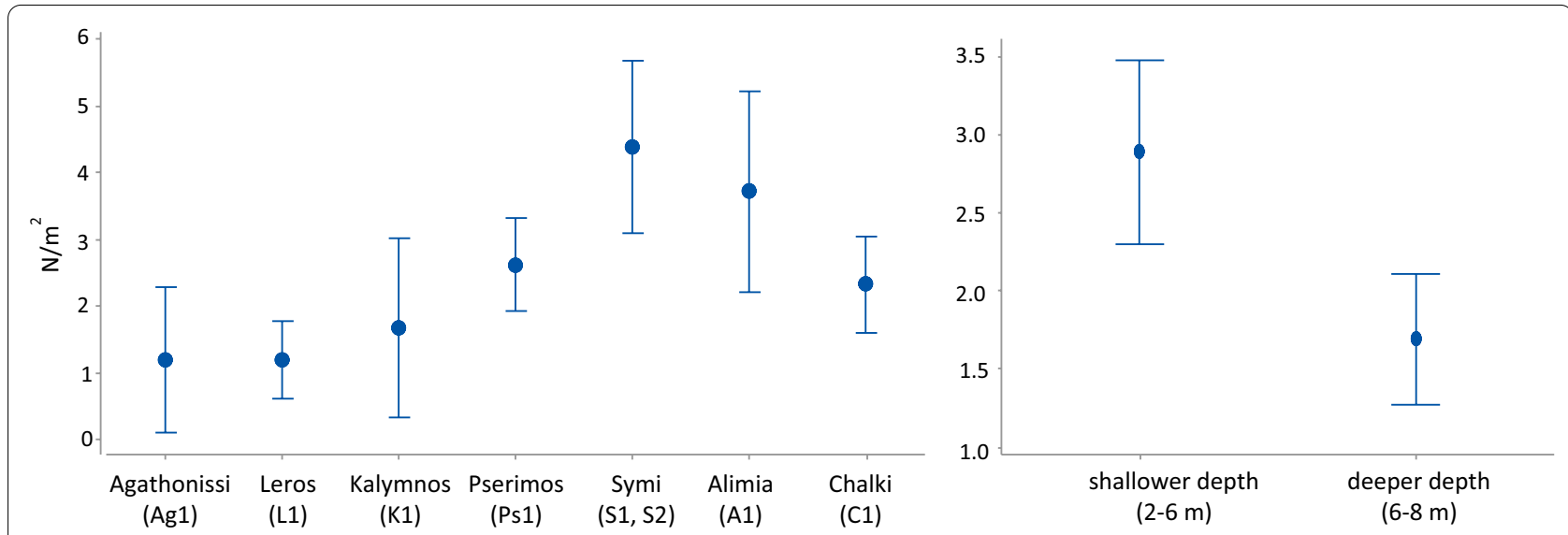

Fig. 2 Mean population density \pm Fisher LSD of Diadema setosum in the densely populated (A, C or F relative abundance grade) islands (left) and in the two depth zones (right) surveyed

Table 2 ANOVA results of the spatial effects on biometry ( $\mathrm{Ht}=$ test height, $\mathrm{Dt}=$ test diameter,) and biomass (tW= total weight) of the surveyed Diadema setosum population in the Dodecanese island complex (south Aegean Sea)

\begin{tabular}{|c|c|c|c|c|c|c|c|}
\hline \multirow[t]{2}{*}{ Source of variation } & \multirow[b]{2}{*}{ df } & \multicolumn{2}{|l|}{$\mathrm{Ht}$} & \multicolumn{2}{|l|}{$\mathrm{Dt}$} & \multicolumn{2}{|l|}{$\mathrm{tw}$} \\
\hline & & $\mathbf{F}$ & $p$ & $\mathbf{F}$ & $p$ & $F$ & $p$ \\
\hline Islands & 6 & 11.88 & 0.0001 & 10.77 & 0.0001 & 14.92 & 0.0001 \\
\hline Depth & 1 & 48.43 & 0.0001 & 67.14 & 0.0001 & 76.41 & 0.0001 \\
\hline
\end{tabular}

level: ts $=-7.52$ ), and 0.57 for $\mathrm{Ht} / \mathrm{Dt}$ (t-test results under the null hypothesis of $\mathrm{b}=1$ at $95 \%$ confidence level: ts $=-37.76$ ). All three relationships had very high determination coefficient $(>90 \%)$ and thus, test diameter or height measurements proved to be efficient predictors of the urchin's body mass.

Overall, 40 specimens were dissected to assess the reproductive status of the studied population; 20 from stations sampled in mid-December and another 20 from stations sampled late June to early July. Collection days were close to full moon in both seasons. In December, all sea urchins were in the recovering stage (Fig. 8A), whereas in June-July mature stages (Fig. 8B and 8C) prevailed in both male and female urchins $(85 \%$ of the dissected specimens). In summer, immature urchins measured less than $3 \mathrm{~cm}$ in Dt from the shallow Alimia station (A1), whereas in December specimens ranged from 3.5 to $7.5 \mathrm{~cm}$ Dt.

\section{Discussion}

It is difficult to evaluate the population status of Diadema setosum in the Mediterranean basin, after its successful invasion in 2006, as published data refer exclusively on the presence of the species (see Table 3) without any information on abundance, density or size structure. It is fairly evident, however, that the species has established populations in many locations along the Levantine and south, south-eastern Aegean Sea, and that D. setosum is further expanding towards the north Aegean and the Ionian Sea (see confirmed records in Table 3).

Diadema species are pervasive, especially on shallow rocky and reef habitats [27]. A patchy distribution pattern of many Diadema species, including D. setosum, with hidden individuals and large local aggregations has been reported from many studied populations ([1] and references therein). In the currently surveyed marine area of the Dodecanese, $D$. setosum forms sparse populations of well-hidden individuals in rocky crevices, but with dense localized patches in specific sites, such as Symi, Alimia and Chalki islands. Although not fully understood, this pattern may be attributed to the prevailed flows of surface water currents affecting larval transport [28-30] or to gregarious settlement of young recruits and adults as an adaptive strategy to better defend against predators [1].

The oligotrophic nature of the study area, leading to low algal biomass productivity levels [31], creates feeding constraints for many invertebrates [32, 33]. This may be another factor against the establishment of dense $D$. setosum populations, except of specific areas, such as ports (Chalki island), aquaculture facilities (Symi island), thermal springs (Kalymnos island), and shelter bays (Alimia 


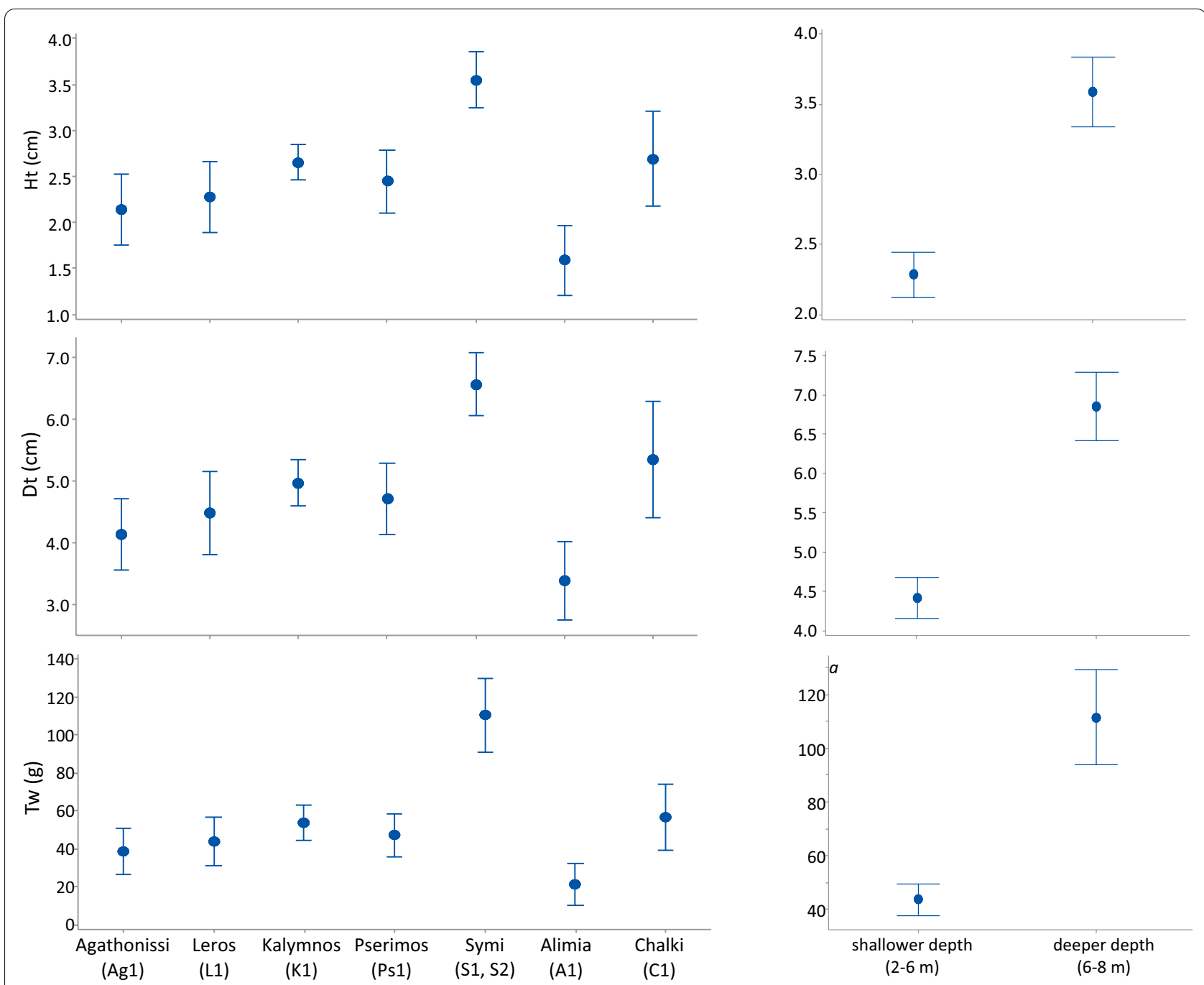

Fig. 3 Mean size $(\mathrm{Ht}=$ test height, $\mathrm{Dt}=$ test diameter) and biomass ( $\mathrm{tW}=$ total weight) \pm Fisher LSD of Diadema setosum in the densely populated (A, C or F relative abundance grade) islands (left) and in the two depth zones (right) surveyed

island), where algal coverage can support the trophic needs of this omnivorous sea urchin species $[1,8]$. Direct competition with herbivorous fishes, such as the NIS Siganus spp. that thrives in the study area [34], may also have affected $D$. setosum densities. Unfortunately, there are no specific studies on intraspecific competition of herbivorous species or on their effects on algal coverage in the Dodecanese.

In the current study, several stations with dense patches of D. setosum have been detected mostly at the south-eastern part of Dodecanese, especially in Kalymnos, Symi, Chalki and Alimia; in those sites, the species density varied from 0.8 to 5.3 individuals $\mathrm{m}^{-2}$. Unfortunately, there are no other relevant data to compare the density of $D$. setosum within the Mediterranean Sea. By considering non-Mediterranean populations, where the species' density ranges from 0.01 to 7.5 individuals $\mathrm{m}^{-2}$ in Kenyan reefs [1], from 2.2 to 6.05 individuals $\mathrm{m}^{-2}$ in Thailand reefs [35] and from 0.32 to 5.92 individuals $\mathrm{m}^{-2}$ in Hong Kong rocky reefs [13], the reported densities in the present study may be considered as moderate. Natural recruitment combined with overfishing of $D$. setosum primary predators have been proposed long ago to explain dense populations of the species [36]. However, recruitment studies on the congeneric $D$. antillarum showed great variability in spatiotemporal scales and were independent of adults' density ([1] and references therein).

In the present study, the abundance of $D$. setosum decreased towards the deeper depth zone surveyed, i.e., below 5-6 $\mathrm{m}$. The typical depth distribution of $D$. setosum usually ranges from the surface down to $10 \mathrm{~m}$ depth 


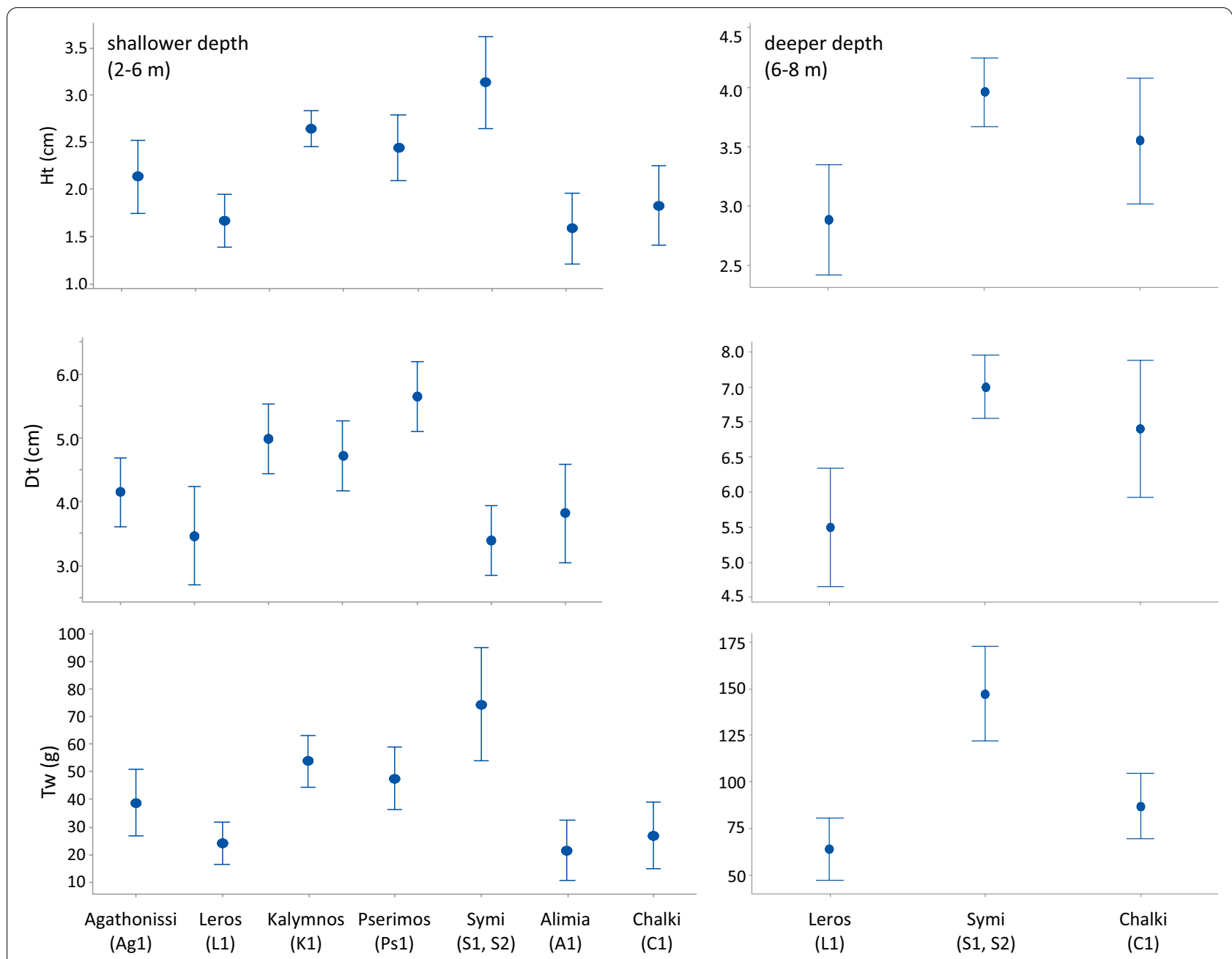

Fig. 4 Mean size $(\mathrm{Ht}=$ test height, $\mathrm{Dt}=$ test diameter) and biomass ( $\mathrm{tW}=$ total weight) \pm Fisher LSD of Diadema setosum in the densely populated ( $A, C$ or $F$ relative abundance grade) islands in the shallower (left) and lower (right) depth distribution of the species

[37]. The studied sea urchin population constituted of much larger individuals in the deeper zone, as well. These results suggest a size-segregated pattern with depth, which might be explained by environmental differences, such as wave exposure, and rocky shore topography. Dislodgement risk by hydrodynamics induced by wave action has been assigned as the main factor driving the vertical distribution patterns of several sea urchin species, including those of the genus Diadema [38]. Specific data for $D$. setosum are missing, but according to relevant data for its congeneric $D$. antillarum, increased water movement practically restricts the distribution of the species at the shallowest strata of the rocky shores. The morphology of Diadema spp. is less adapted to resist water motion and its spines are extremely fragile and cannot support attachment to the substrate [38]. Accordingly, the species thrives in the deeper, low-flow, part of the reefs. In the surveyed wave-swept rocky shores, the shallower part (usually the first 2-3 m) was very steep, smooth and compact, without forming crevices, holes or other sub-horizontal structures that could offer refuge to D. setosum. Deeper down, the substrate was more heterogenous with many crevices and sub-horizontal formations constituting a much-preferred microhabitat for the species (authors' personal observations).

According to the size-frequency distribution analysis, the studied D. setosum population is composed of medium and large sized individuals, in the shallower and deeper zones of its bathymetric distribution. Test diameter was an excellent predictor of the urchin's biomass, whereas the growth of $D$. setosum followed negative allometry, as previously suggested for the species within its native range of distribution [39]. Test diameter or height increased at a relatively faster rate than its weight, and the same stands for two-dimensional growth $(\mathrm{Ht} / \mathrm{Dt})$ as well. This pattern may reflect the need for $D$. setosum specimens to quickly attain 


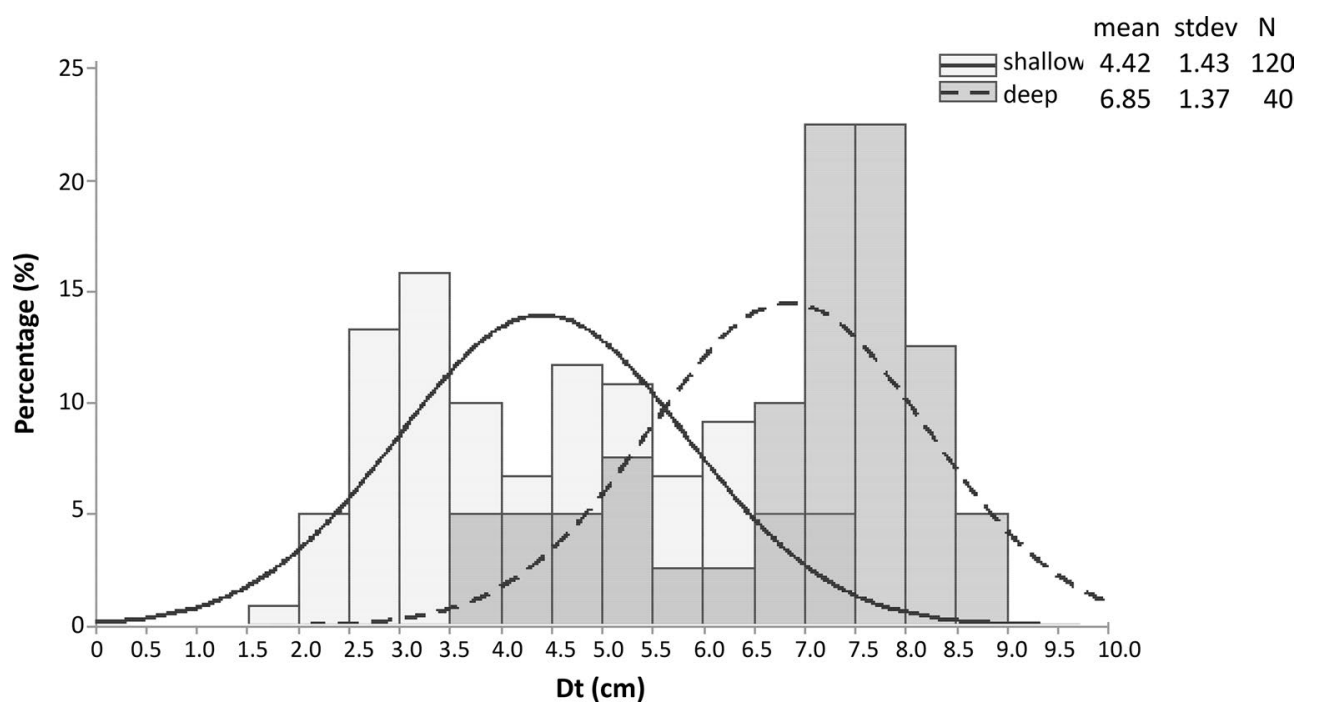

Fig. 5 Size ( $\mathrm{Dt}$ = test diameter)—frequency distribution of the studied Diadema setosum population per depth distribution zones surveyed (data were pooled over stations and islands)

a large diameter to face predation, as small individuals may be more susceptible to fish predation [1]. Diadema setosum has a short initial growth rate in contrast to its congeners, though the reported rates vary between different populations [1]. This initial slow growth may explain the slow colonization rate of this ubiquitous species, as it took about five years to be detected again after its first report in Kas Peninsula. However, the size range of the studied specimens suggest the presence of mature and reproductive population in the Dodecanese area.

The reproduction of $D$. setosum varies greatly from one geographic location to another, with moonlight, tidal rhythms, age/size of urchins, and food availability among the factors influencing gametogenesis and spawning behavior [1]. The species reproduces throughout the year in the tropics, but with peaks at different times of the year [40]. In temperate populations, the species spawns in summer and seawater temperature is assumed to be the driving factor with values above $25^{\circ} \mathrm{C}$ triggering gametogenesis $[9,11]$. Though this study did not attempt to describe precisely the reproductive biology of $D$. setosum, it confirms the presence of mature specimens in all densely populated station during summer. In contrast, all examined individuals were at recovering stage in winter. These results conform to the reported breeding season from temperate areas.

\section{Conclusions}

Diadema setosum has successfully invaded the Mediterranean basin, as well-established and flourish populations can be found in the Levantine basin and the south
Aegean Sea. The species has sparse populations in the shallow rocky sublittoral zone $(<10 \mathrm{~m})$ with locally dense patches of mature individuals in many islands of the Dodecanese. The studied population is probably shaped by a combination of environmental (habitat type, hydrodynamics) and biotic factors (recruitment, interspecific competition). As a keystone competitive superior [41] grazer, $D$. setosum may have a profound effect shaping benthic communities. In all densely populated surveyed stations, interestingly, it was the only sea urchin species found, as neither Arbacia lixula nor Paracentrotus lividus, the two most common regular sea urchins in the Aegean Sea and the Dodecanese [42-44], were observed. Further spread of D. setosum in the near future has been already implied [5] and is further supported by presented results. Accordingly, the implementation of a monitoring scheme to gather essential biological information together with efforts to manage and control the establishment of $D$. setosum-possible exploitation of its gonads [45] or bioactive compounds [14] —and prevent further expansion of this invasive species are urgently needed.

\section{Methods}

\section{Study area}

The study was carried out at the Dodecanese island complex, located in the south Aegean Sea. In the marine area of the Dodecanese, water masses are warm $\left(16-27^{\circ} \mathrm{C}\right)$, saline (around 39-40 psu) and oligotrophic [32, 33]. One to four stations were selected at random on each of the sixteen surveyed islands (Fig. 1); most of them are continental in geologic origin, whereas Nisyros and Gialy 


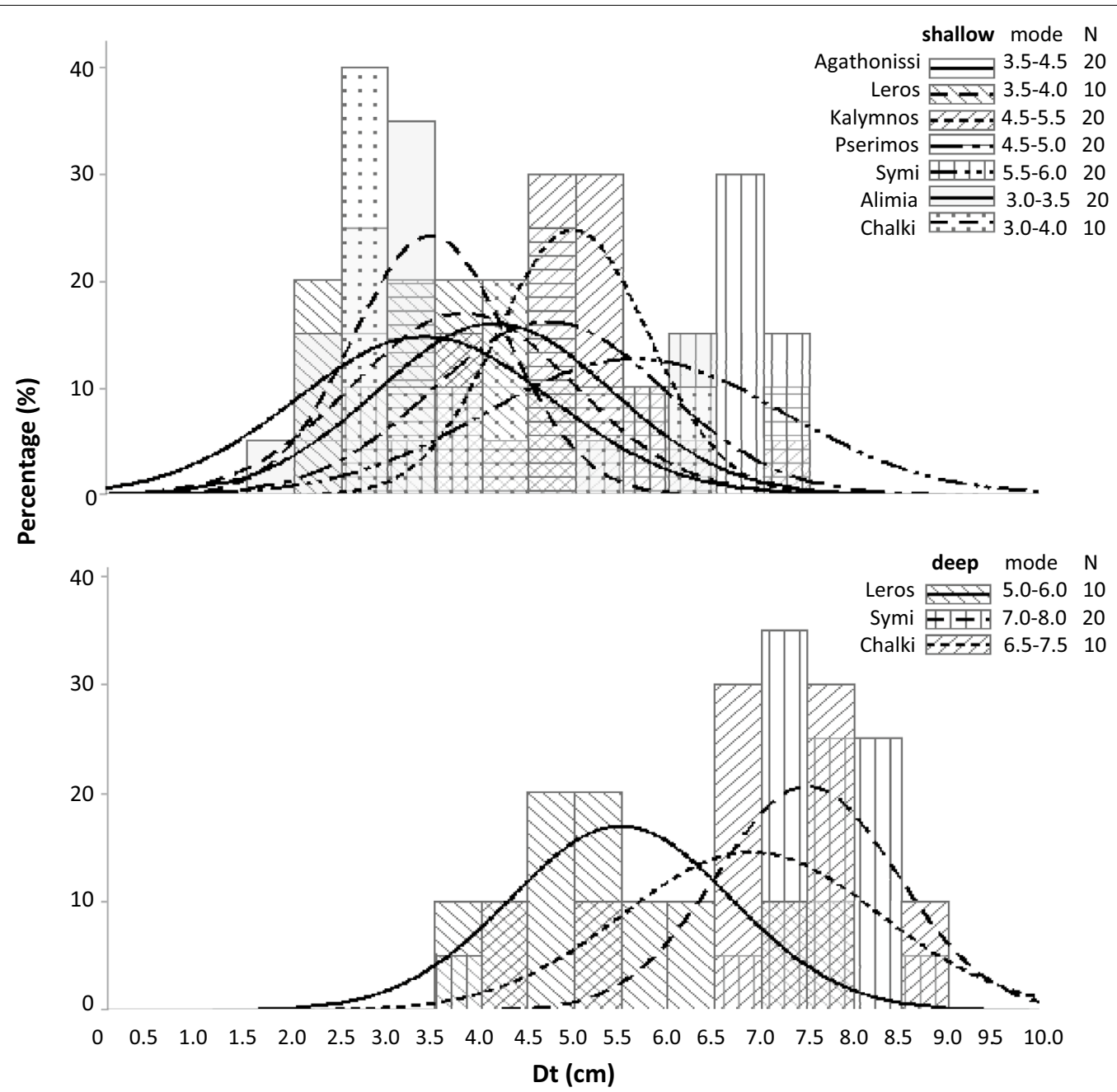

Fig. 6 Size (Dt =test diameter) — frequency distribution of the studied Diadema setosum population per island, in the shallower (top graph) and deeper (lower graph) depth distributional zone of the species

are of volcanic origin [46]. Samplings were made in December 2019, and in June \& July 2020, by scientific SCUBA diving in the shallow sublittoral zone, i.e., up to $10 \mathrm{~m}$ depth. They included a combination of visual census and random collection of $D$. setosum specimens to assess abundance and basic characteristics of the species' population. At all stations, the sea bottom consisted of rocky substrates mixed with patches of sandy detritic sediments and interspersed Posidonia oceanica beds. The main geomorphological features of sampling stations are given in Table 1.

\section{Abundance and biometry}

The semi-quantitative ACFOR scale of relative abundance $[47,48]$ was applied to broadly estimate the spatial patterns of the species density, by diving along three replicate transects $500 \mathrm{~m}$, each. The ACFOR scale has five categories, modified as follows to better fit the size of the studied species. A=abundant, a species found almost everywhere, expanding to over $40 \%$ of the surveyed area, and/or with over 50 individuals per $100 \mathrm{~m}^{2}$. $\mathrm{C}=$ common, a species found almost everywhere but not as dominant as in A, expanding from 20 to $40 \%$ of 


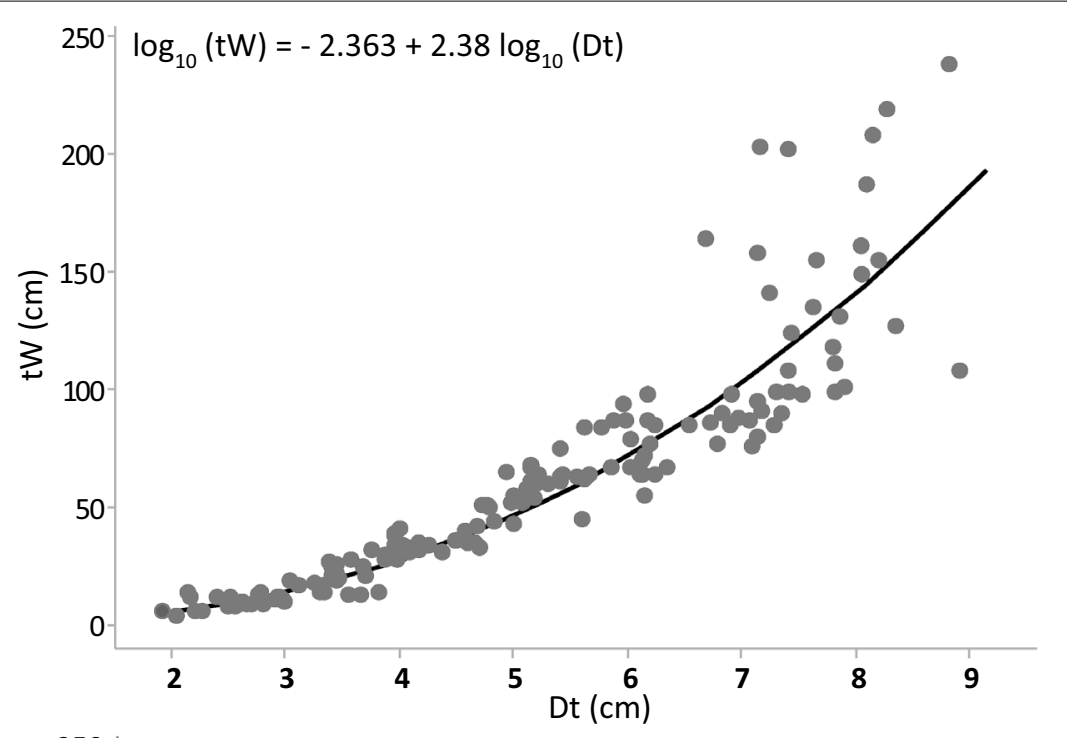

$$
\begin{aligned}
& R^{2}=93.2 \% \\
& n=140
\end{aligned}
$$
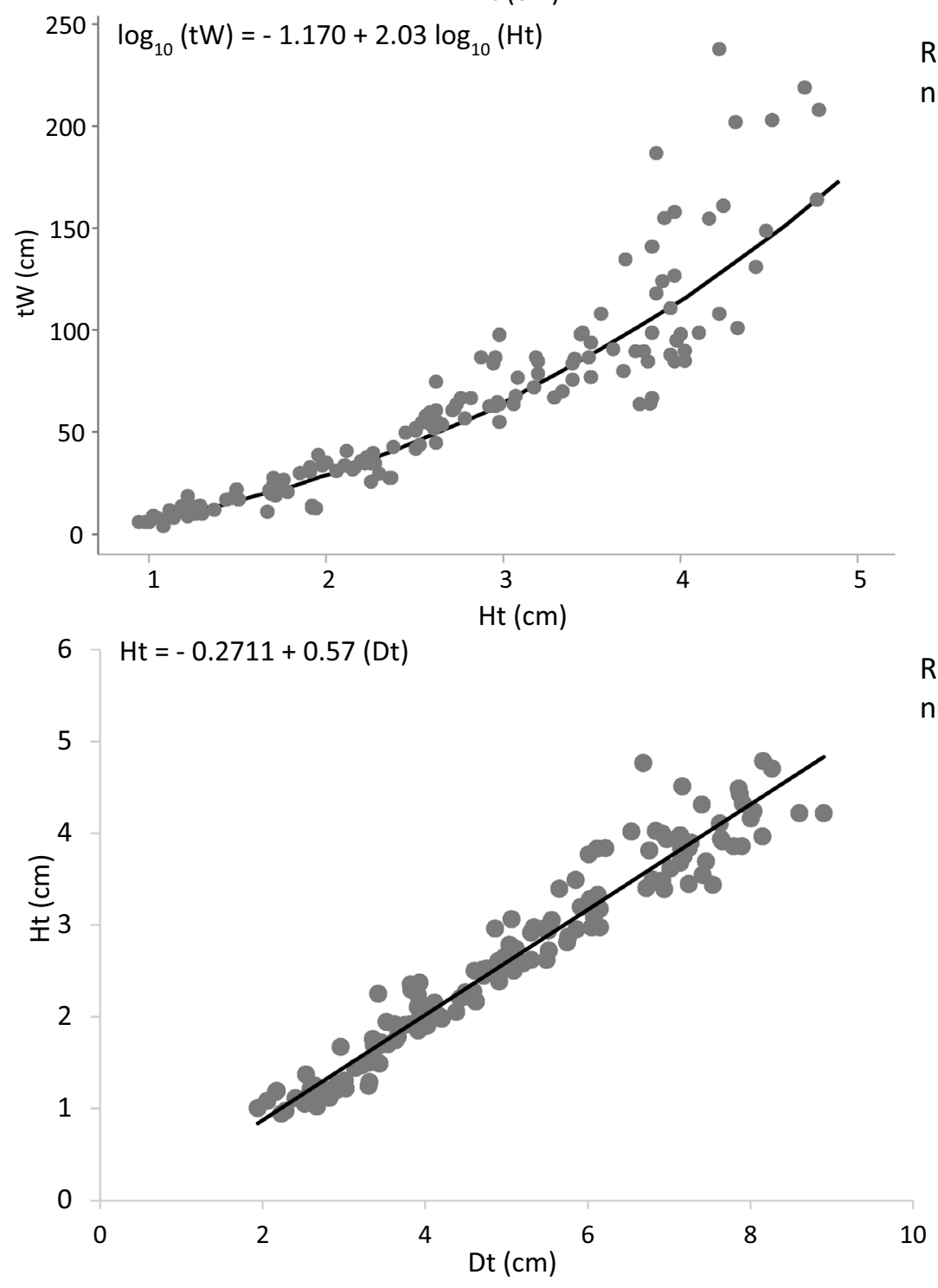

$R^{2}=94.2 \%$

$\mathrm{n}=140$

$R^{2}=93.1 \%$

$\mathrm{n}=140$ 

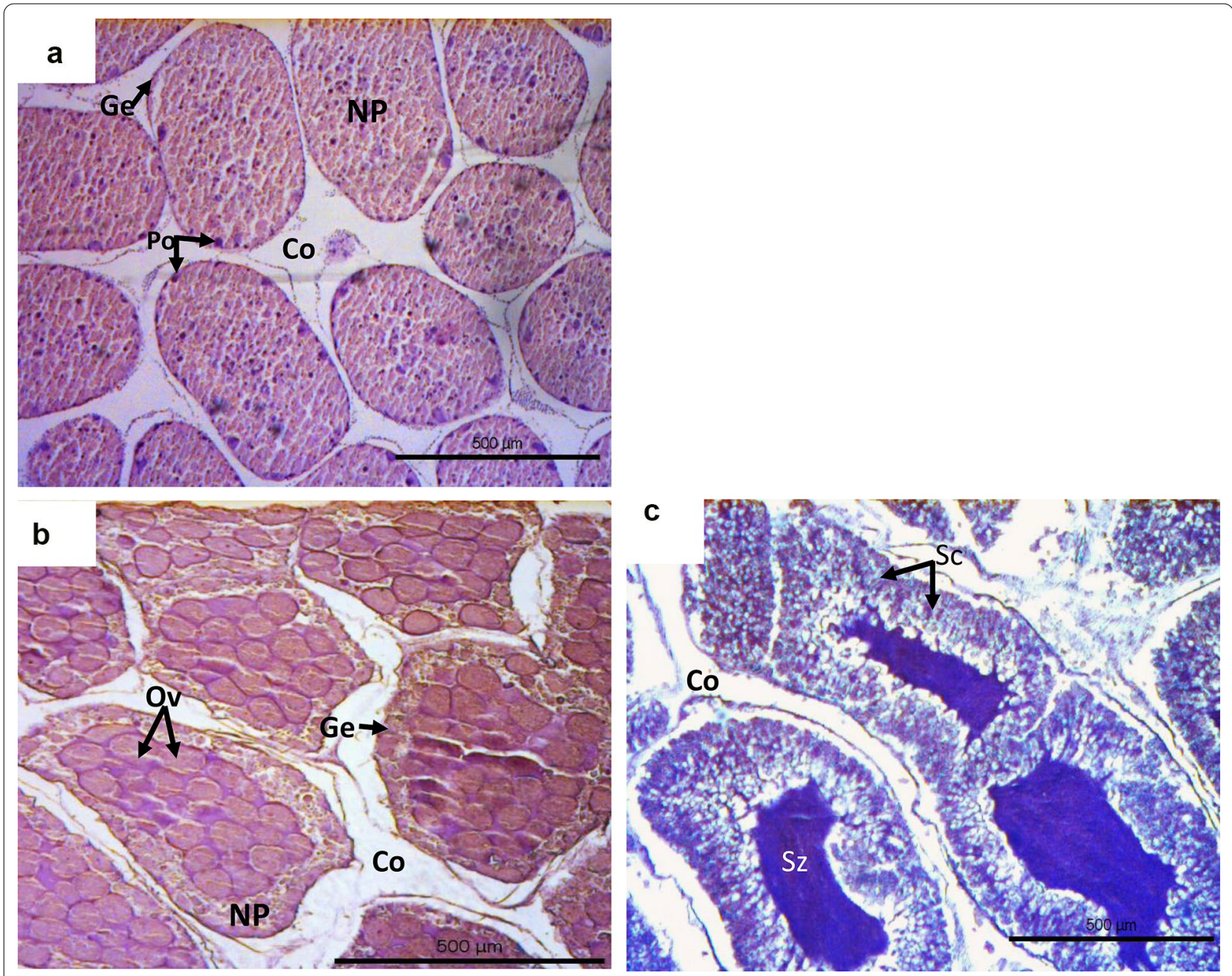

Fig. 8 Reproductive stages according to Bronstein et al. [11] of the studied Diadema setosum population in Dodecanese island complex, observed in December 2019 and July 2020 samplings. A Stage II (recovering): clusters of previtellogenic oocytes formed in the ovarian germinal epithelium which may also occupy the central space of the female gametes. B, C Stage IV (mature): Ovaries (B) and testicular lumen (C) packed with mature ova and spermatozoa, respectively. Oocytes at different maturation stages are distinguished in the germinal epithelium. Ge germinal epithelium, Co coelom, NP nutritive phagocytes, Po previtellogenetic oocytes, Ov ova, Sz spermatozoa, Sc spermatocyte

the surveyed area, and/or with 10 to 50 individuals per $100 \mathrm{~m}^{2} . \mathrm{F}=$ frequent, a species found in many places, expanding from 10 to $20 \%$ of the surveyed area, and/ or with 5 to 10 individuals per $100 \mathrm{~m}^{2}$. $\mathrm{O}=$ occasional, a species found in few places, expanding to $5-10 \%$ of the surveyed area, and/or with 1 to 5 individuals per $100 \mathrm{~m}^{2} . \mathrm{R}=$ rare, a species found in one or two places, expanding to $1-5 \%$ of the surveyed area and with less than 1 individual per $100 \mathrm{~m}^{2}$. When a species is found in the surveyed area but with meaningful abundance is assessed as present (P), while when being apparently absent from the surveyed area as no present (NP). Concurrently, seawater temperature, salinity, $\mathrm{pH}$, and dissolved oxygen were recorded with an autographic conductivity-temperature-depth sensor, CTD (SeaBird Electronics, Washington USA).

At the stations having F or higher abundance grade, a more precise estimation of the species abundance was made. In those cases, population density was directly estimated using belt transect sampling [33, 49]. Thus, four replicate transects $1 \times 10 \mathrm{~m}-$ covering $10 \mathrm{~m}^{2}$ each-were conducted at each station. In stations where the sea urchins expanded over a broad depth range, the replicate transects were equally dispersed at the shallower, i.e., $2-4 \mathrm{~m}$, and the deeper, i.e., 6-8 m, depths, of these zones; transects were parallel to each depth contour. Along each transect, all living $D$. setosum individuals were counted, and five sea 
Table 3 Confirmed records of the NIS Diadema setosum in the Mediterranean ( $\mathrm{N}=$ number of observed individuals, ND=no data provided)

\begin{tabular}{|c|c|c|c|c|c|c|}
\hline Geographic area & Latitude/Longitude & Year & Depth & Substrata & $\mathbf{N}$ & References \\
\hline \multicolumn{7}{|l|}{ Turkey } \\
\hline Kas Peninsula & $36^{\circ} 08^{\prime} 27^{\prime \prime} \mathrm{N} 09^{\circ} 39^{\prime} 18^{\prime \prime} \mathrm{E}$ & 2006 & $15-18$ & Rocky & 2 & {$[2]$} \\
\hline Antakya Bay & $35^{\circ} 57^{\prime} 20^{\prime \prime} \mathrm{N} 35^{\circ} 55^{\prime} 20^{\prime \prime} \mathrm{E}$ & 2010 & 9 & Rocky & 3 & [16] \\
\hline Gokova Bay & $36^{\circ} 55^{\prime} 11^{\prime \prime} \mathrm{N} 28^{\circ} 10^{\prime} 16^{\prime \prime} \mathrm{E}$ & 2014 & 4 & Rocky, sandy & 2 & {$[17]$} \\
\hline Dardanelles & $40^{\circ} 24^{\prime} 12^{\prime \prime} \mathrm{N} 26^{\circ} 45^{\prime} 43^{\prime \prime} \mathrm{E}$ & 2018 & $4-6$ & Rocky & - & [23] \\
\hline \multicolumn{7}{|l|}{ Greece } \\
\hline Kastelorizo & $36^{\circ} 09^{\prime} 10^{\prime \prime} \mathrm{N} 29^{\circ} 35^{\prime} 30^{\prime \prime} \mathrm{E}$ & 2014,2015 & $3-5$ & Rocky & 5 & [18] \\
\hline Pserimos & $36^{\circ} 56^{\prime} 36^{\prime \prime} \mathrm{N} 27^{\circ} 09^{\prime} 53^{\prime \prime} \mathrm{E}$ & 2016 & $2 / 15$ & ND & 2 & [22] \\
\hline Mandraki, Rhodos & $36^{\circ} 26^{\prime} 57^{\prime \prime} \mathrm{N} 28^{\circ} 13^{\prime} 41^{\prime \prime} \mathrm{E}$ & 2015 & 6 & Rocky & 1 & [19] \\
\hline Kolokytha, Crete & $35^{\circ} 15^{\prime} 24^{\prime \prime} \mathrm{N} 25^{\circ} 44^{\prime} 31^{\prime \prime} \mathrm{E}$ & 2016 & 5 & Rocky & 1 & [20] \\
\hline Proti Island & $37^{\circ} 02^{\prime} 39^{\prime \prime} \mathrm{N} 21^{\circ} 33^{\prime} 32^{\prime \prime} \mathrm{E}$ & 2020 & $6 / 15$ & ND & $8 / 1$ & {$[26]$} \\
\hline Kythira Island & $36^{\circ} 09^{\prime} 31^{\prime \prime} \mathrm{N} 22^{\circ} 56^{\prime} 57^{\prime \prime} \mathrm{E}$ & 2020 & $4 / 27$ & ND & 2 & [26] \\
\hline Avlemonas, Kythira & $36^{\circ} 13^{\prime} 31^{\prime \prime} \mathrm{N} 23^{\circ} 04^{\prime} 52^{\prime \prime} \mathrm{E}$ & & & & & [25] \\
\hline Archangelos, Laconia & $36^{\circ} 37^{\prime} 44^{\prime \prime} \mathrm{N} 22^{\circ} 52^{\prime} 35^{\prime \prime} \mathrm{E}$ & 2019 & 2 & Rocky & 1 & {$[25]$} \\
\hline Pedi Bay, Symi & $36^{\circ} 36^{\prime} 48^{\prime \prime} \mathrm{N} 27^{\circ} 51^{\prime} 22^{\prime \prime} \mathrm{E}$ & 2018 & 0.5 & Rocky & 2 & [24] \\
\hline Gialos Bay, Symi & $36^{\circ} 37^{\prime} 13^{\prime \prime} \mathrm{N} 27^{\circ} 50^{\prime} 18^{\prime \prime} \mathrm{E}$ & 2019 & $0.5-2.5$ & Rocky & 4 & [24] \\
\hline \multicolumn{7}{|l|}{ Cyprus } \\
\hline Cyclop's Bay & $34^{\circ} 04^{\prime} 46^{\prime \prime} \mathrm{N} 34^{\circ} 59^{\prime} 09^{\prime \prime} \mathrm{E}$ & 2012,2016 & $10-13$ & Rocky & 2 & [21] \\
\hline Decosta Bay & $35^{\circ} 00^{\prime} 27^{\prime \prime} \mathrm{N} 34^{\circ} 03^{\prime} 43^{\prime \prime} \mathrm{E}$ & 2012 & $1 / 10$ & Sandy, rocky & 2 & {$[21]$} \\
\hline \multicolumn{7}{|l|}{ Lebanon } \\
\hline \multirow[t]{2}{*}{ Monsef } & $34^{\circ} 10^{\prime} 59^{\prime \prime} \mathrm{N} 35^{\circ} 37^{\prime} 55^{\prime \prime} \mathrm{E}$ & 2009 & $10-20$ & Rocky & 1 & {$[15]$} \\
\hline & & 2019 & 2.5 & Rocky & 1 & [25] \\
\hline \multicolumn{7}{|l|}{ Israel } \\
\hline Tel Aviv & $32^{\circ} 05^{\prime} 01^{\prime \prime} \mathrm{N} 34^{\circ} 45^{\prime} 46^{\prime \prime} \mathrm{E}$ & 2016 & $3.5-8$ & Rocky & 1 & {$[5]$} \\
\hline
\end{tabular}

urchin specimens were randomly collected to estimate the size structure of the studied population. The fresh sea urchin specimens were measured on board for test diameter (Dt) and height $(\mathrm{Ht})$, at ambitus avoiding spines, using an electronic caliper (Mitutoyo Corporation, Takatsu Ward, Japan, $0.01 \mathrm{~mm}$ precision), and drained for 5-min on filter paper. Each specimen was, then, weighted for total weight ( $\mathrm{tW}$ ) using an electronic scale $(0.01 \mathrm{~g}$ precision). Overall, the sample size for biometry was $160 \mathrm{D}$. setosum individuals.

Analysis of variance was applied to examine differences in population density of $D$. setosum between islands and depths (both treated as fixed factors) using the general linear model [50]. The same analysis was applied to examine relevant spatial differences in the estimated biometric variables (Dt, $\mathrm{Ht}, \mathrm{tW})$ of the sea urchin. Prior to the analyses, data were tested for normality with the Anderson-Darling test, while the homogeneity of variances was tested with Cohran's test and, when necessary, data were log-transformed. The Fisher LSD test was used for post hoc comparisons. ANOVAs were performed using the SPSS software package (IBM SPSS statistics v.25, IBM Corp, Armonk, New York, USA).
Size frequency distributions were constructed per $0.5 \mathrm{~cm}$ size class increments using Dt data [35], and the modal length was identified by fitting a normal distribution curve [51].

Morphometric relationships, i.e., height/diameter, weight/diameter and weight/height, were estimated using the linear $(\mathrm{Ht}=\mathrm{a}+\mathrm{bDt})$ or the power function $\left(\mathrm{tW}=\mathrm{aDt}^{\mathrm{b}}\right.$ which equals to LogtW $=\log \mathrm{a}+\mathrm{bLogDt}$ and $\mathrm{tW}=\mathrm{aHt}^{\mathrm{b}}$ which equals to $\log \mathrm{W} \mathrm{W}=\log \mathrm{a}+\mathrm{bLogHt}$ ) and applying a regression analysis. The association degree between variables was calculated by the determination coefficient $\left(\mathrm{R}^{2}\right)$, while a t-test with a confidence level of 95\% was applied to detect whether the relative growth rates of the urchins' biometric characters were isometric (Ho: $b=1$ for $\mathrm{Ht} / \mathrm{Dt}$ or $\mathrm{b}=3$ for $\mathrm{tW} / \mathrm{Dt}$ and $\mathrm{tW} / \mathrm{Ht}$ ) or allometric ( $\mathrm{H} 1 \mathrm{~b}, \mathrm{~b} \neq 1$ for $\mathrm{Ht} / \mathrm{Dt}$ or $\mathrm{b} \neq 3$ for $\mathrm{tW} / \mathrm{Dt}$ and $\mathrm{tW} / \mathrm{Ht})$.

\section{Histology}

Five of the collected (collection days: 11-12/12/2019 and 3-6/7/2020 were close to full moon: $12 / 12 / 2019$, $5 / 7 / 2020$, in both seasons) sea urchin specimens for biometry at each station were dissected to remove 
the five gonads, which were immediately fixed in $10 \%$ neutral buffered formalin solution. Fixed gonads were further processed in the laboratory to assess the reproductive status of the sea urchins using histological examination $[49,52]$. The middle portions of each specimen gonadal tissues were placed in cassettes and inputted in histokinette (Leica TP 1020, Leica Microsystems GmbH, Nussloch, Germany) for dehydration (immersion in ethanol solution of increasing concentrations), clearing (immersion in xylene solutions to replace ethanol with an organic dissolvent), and embedding in liquid paraffin wax. The gonadal tissue paraffin blocks were left for cooling (Leica EG $1150 \mathrm{H}$ Leica Microsystems GmbH, Nussloch, Germany); then, the mold was removed and the blocks were mounted on a microtome (Slee Mainz Cut 5062, SLEE medical GmbH, Mainz, Germany) for sectioning $(5 \mu \mathrm{m}$ sections). The sections were stained with the hematoxylin-eosin regressive staining procedure [49, 52], covered with Canada balsam mounting medium, and observed under light microscopy connected with a digital camera (ProgRes Plus 2.1, JENOPTIC Optical Systems GmbH, Jena, Germany). The histological sections were photographed in appropriate magnification scale using the software Progress Capture 2.1. The different developmental stages of gametogenesis were assessed according to Bronstein et al. (2016) [11].

\section{Abbreviations}

NIS: Non indigenous species; ACFOR scale: $A=$ abundant, $C=$ common, $\mathrm{F}=$ frequent, $\mathrm{O}=$ occasional, $\mathrm{R}=$ rare relative abundance scale; $\mathrm{Dt}$ : Test diameter; Ht: Test height; tW: Total weight; SFD: Size frequency distribution.

\section{Acknowledgements}

We are grateful to the Coastal Fishermen Association of Kalymnos "PanagiaYpapanti", the Sponge-Fishermen Association of Kalymnos, and the captain and the crew of the vessel "Ag Pavlos SK230" for their help during samplings.

\section{Authors' contributions}

DV conceptualized the project, data validation and reviewing of the draft manuscript, CA experimental field samplings, abundance data analyses, writing of the draft manuscript and editing the final manuscript, ChA histology and data analyses, KV and AV experimental field samplings and biometry data analyses. All authors read and approved the final manuscript.

\section{Funding}

This work received no funding.

\section{Availability of data and materials}

The datasets used and/or analyzed during the current study are available from the corresponding author on reasonable request.

\section{Declarations}

\section{Ethics approval and consent to participate}

We attest that this research has ethics approval, as there is no specific ethical framework for the usage of sea urchins in marine research and we did not perform any experimental treatment that could torture the collected specimens (immediately preserved).
Consent for publication

Not applicable.

\section{Competing interests}

The authors declare that they have no competing interests.

\section{Author details}

${ }^{1}$ School of Agricultural Sciences, Department of Ichthyology and Aquatic Environment, University of Thessaly, 38445 Nea Ionia, Magnesia, Greece.

${ }^{2}$ School of Biology, Department of Zoology, Aristotle University of Thessaloniki, 54124 Thessaloniki, Greece.

Received: 2 March 2021 Accepted: 13 May 2021

Published online: 21 May 2021

\section{References}

1. Muthiga NA, McClanahan TR. Diadema. In: Lawrence J, editor. Sea urchins: biology and ecology. Elsevier; 2020. p. 397-418.

2. Yokes B, Galil BS. The first record of the needle-spined urchin Diadema setosum (Leske, 1778) (Echinodermata: Echinoidea: Diadematidae) from the Mediterranean Sea. Aquat Invasions. 2006;3:188-90.

3. Galil BS, Marchini A, Occhipinti-Ambrogi A. East is east and West is west? Management of marine bioinvasions in the Mediterranean Sea. Estuar Coast Shelf Sci. 2016;201:7-16.

4. Lessios HA, Kessing BD, Pearse JS. Population structure and speciation in tropical seas: global phylogeography of the sea urchin Diadema. Evolution. 2001;55:955-75.

5. Bronstein $\mathrm{O}$, Kroh A. Needle in a haystack-genetic evidence confirms the expansion of the alien echinoid Diadema setosum (Echinoidea: Diadematidae) to the Mediterranean coast of Israel. Zootaxa. 2018;4497:593-9.

6. Ebert TA. Estimating mortality from growth parameters and a size distribution when recruitment is periodic. Limnol Oceanogr. 1981;26:764-9.

7. Bronstein O, Loya Y. Echinoid community structure and rates of herbivory and bioerosion on exposed and sheltered reefs. J Exp Mar Biol Ecol. 2014:456:8-17.

8. Stephenson A. The breeding of reef animals. Part II: invertebrates other than corals. Sci Rep Great Barrier Reef Exped. 1934;3:247-72.

9. Pearse JS. Reproductive periodicities of Indo-Pacific invertebrates in the Gulf of Suez. III. The echinoid Diadema setosum (Leske). Bull Mar Sci. 1970;20:697-720.

10. Alsaffar AH, Lone KP. Reproductive cycles of Diadema setosum and Echinometra mathaei (Echinoidea: Echinodermata) from Kuwait (northern Arabian Gulf). Bull Mar Sci. 2000;67:845-56.

11. Bronstein $\mathrm{O}$, Kroh A, Loya Y. Reproduction of the long-spined sea urchin Diadema setosum in the Gulf of Aqaba-implications for the use of gonad indexes. Sci Rep. 2016;6:29569.

12. Ishikawa T, Kurashima A. Estimation of the feeding pressure of a sea urchin (Diadema setosum) population on a barren ground in a temperate region of Japan. Plankton Benthos Res. 2020;15:112-20.

13. Dumont CP, Lau DCC, Astudillo JC, Fong KF, Chak STC, Qiu J-W. Coral bioerosion by the sea urchin Diadema setosum in Hong Kong: susceptibility of different coral species. J Exp Mar Biol Ecol. 2013;441:71-9.

14. Abdelkarem FM, Desoky EEK, Nafady AM, Allam AE, Mahdy A, Ashour A Shimizu K. Diadema setosum: isolation of bioactive secondary metabolites with cytotoxic activity toward human cervical cancer. Nat Prod Res. 2020. https://doi.org/10.1080/14786419.2020.1855162.

15. Nader MR, Indary SL. First record of Diadema setosum (Leske, 1778) (Echinodermata, Echinoidea, Diadematidae) from Lebanon, Eastern Mediterranean. Aquat Invasions. 2011;6:23-5.

16. Turan C, Erguden D, Uygur N. On the occurrence of Diadema setosum (Leske, 1778) in Antakya Bay, Eastern Mediterranean Sea. J Black Sea/ Medit Environ. 2011;17:78-82.

17. Yapici S, Turan C, Türker A. First record of the alien sea urchin Diadema setosum (Leske, 1778) (Echinodermata: Echinoidea: Diadematidae) from the Aegean Sea. New Mediterranean Biodiversity Records (October 2014). Medit Mar Sci. 2014;15:675-95.

18. Latsoudis P. First record of the alien sea urchin Diadema setosum (Echinodermata: Echinoidea: Diadematidae) in Hellenic waters. 
New Mediterranean Biodiversity Records (July 2015). Medit Mar Sci. 2015;16:472-88

19. Kondylatos G, Corsini-Foka M. Diadema setosum moving west to the Hellenic Seas. New Mediterranean Biodiversity Records (October 2015). Medit Mar Sci. 2015;16:682-702

20. Dounas C, Krystalas A. First record of Diadema setosum (Leske, 1778) from Kriti New Mediterranean Biodiversity Records (November 2016). Medit Mar Sci. 2016;17:794-821.

21. Savva I, Kleitou P. On three alien species from Cyprus (eastern Mediterranean Sea). New Mediterranean Biodiversity Records (July2017). Medit Mar Sci. 2017:18:355-84.

22. Zenetos A, Liami A, Xentidis N, Corsini-Foka M. Marine Alien Species at Pserimos Island (Greece): Census with the help of citizen scientists. J Mar Biolog Assoc UK. 2017;97:629-34.

23. Artüz ML, Artüz OB. First and northernmost record of Diadema setosum (Leske, 1778) (Echinodermata: Echinoidea: Diadematidae) in the Sea of Marmara. Thalassas Int J Mar Sci. 2019;35:375-9.

24. Galanos CJ, Kritikos S. Diadema setosum (Leske, 1778) (Echinodermata Echinoidea, Diadematidae), first record for Simi island, Hellas, eastern Mediterranean. Parnassiana Arch. 2019;7:15-9.

25. Pirkenseer CM. Alien species in southern Laconia, Kythira Island and southern Messenia (Greece): new and additional records and updated record maps. J Black Sea/Medit Environ. 2020;26:145-75.

26. Ragkousis M, Tsatiris A, Katsanevakis S. First record of Diadema setosum (Leske, 1778) in the Ionian Sea New Alien Mediterranean Biodiversity Records (October 2020). Medit Mar Sci. 2020:21:631-52.

27. Bauer JC. Observations on geographical variations in population density of the echinoid Diadema antillarum within the western North Atlantic. Bull Mar Sci. 1980;30:509-15.

28. Williams SM, Garcia Sais JR, Capella J. Temporal variation of early larval stages of the long-spined sea urchin Diadema antillarum in La Parguera, Puerto Rico. Caribb J Sci. 2009;45:110-8.

29. Sameoto J, Ross T, Metaxas A. The effect of flow on larval vertical distribution of the sea urchin Strongylocentrotus droebachiensis. J Exp Mar Biol Ecol. 2010;383:156-63.

30. Feehan CJ, Sharp WC, Miles TN, Brown MS, Adams DK. Larval influx of Diadema antillarum to the Florida Keys linked to passage of a Tortugas Eddy. Coral Reefs. 2019;38:387-93.

31. BosC E, Bricaud A, Antoine D (2004) Seasonal and interannual variability in algal biomass and primary production in the Mediterranean Sea, as derived from 4 years of SeaWiFS observations. Global Biogeochem Cycles 2004;18 GB1005.

32. Antoniadou C, Vafidis D. Population structure of the traditionally exploited holothurian Holothuria tubulosa in the south Aegean Sea. Cah Biol Mar. 2011;52:171-5.

33. Vafidis D, Antoniadou C, Voultsiadou E, Chintiroglou C. Population structure of the protected fan mussel Pinna nobilis in the south Aegean Sea (eastern Mediterranean). J Mar Biolog Assoc UK. 2014;94:787-96.

34. Corsini M, Economidis PS. Distribution extension of two Lessepsian migrants found in the marine area of the island of Rhodes (Aegean Sea, Greece). Cybium. 1999;23:195-9.

35. Buaruang J, Yeemin T, Ruangsawang N, Nopchinwong P, Asa S. Population density, recruitment and size structure of a sea urchin, Diadema setosum, from coral communities in the inner and the eastern Gulf of Thailand. 28th Congress on Science and Technology of Thailand. 2002.

36. Thompson GB. Underwater observations on the distribution of regular sea urchins in Hong Kong. In: Morton B, Tseng CK, editors. The Marine flora and fauna of Hong Kong and Southern China. Hong Kong University Press; 1980. p. 655-71.

37. Pearse JS. Distribution of Diadema savignyi and D. setosum in the tropical Pacific. In: Mooi R, Telford M, editors. Echinoderms: San Francisco. Rotterdam: Balkema; 1998. p. 777-82.

38. Tuya F, Cisneros-Aguirre J, Ortega-Borges L. Bathymetric segregation of sea urchins on reefs of the Canarian Archipelago: role of flow-induced forces. Estuar Coast Shelf Sci. 2007;73:481-8.
39. Rahman MA, Amin SMN, Yusoff FM, Arshad A, Kuppan P, Shamsudin M. Length weight relationships and fecundity estimates of long-spined sea urchin, Diadema setosum, from the Pulau Pangkor, Peninsular Malaysia. Aquat Ecosyst Health Manag. 2012;15:311-5.

40. Muthiga NA. Coexistence and reproductive isolation of the sympatric echinoids Diadema savignyi Michelin and Diadema setosum (Leske) on Kenyan coral reefs. Mar Biol. 2003;143:669-77.

41. McClanahan TR. Resource utilization, competition, and predation: a model and example from coral reef grazers. Ecol Model. 1992;61:195-215.

42. Koukouras A, Sinis Al, Bobori D, Kazantzidis S, Kitsos MS. The echinoderm (Deuterostomia) fauna of the Aegean Sea and comparison with those of the neighboring seas. J Biol Res-Thessalon. 2007;7:67-92.

43. Antoniadou C, Vafidis D. Population structure and morphometric relationships of Paracentrotus lividus (Echinodermata: Echinoidea) in the south Aegean Sea. Cah Biol Mar. 2009;50:293-301.

44. Antoniadou C, Vafidis D. Population ecology of common sea urchins (Arbacia lixula, Paracentrotus lividus, Sphaerechinus granularis) on algaldominated rocky shores in the Aegean Sea. In: Whitmore E, editor. Echinoderms. Nova Science Publishers; 2014. p. 147-66.

45. Salma WD, Hafizah I, Nurtamin T, Haya LOMY, As'ad S. The potential gonad of Diadema setosum as a healthy food to improve the nutritional status of coastal children. Int J Sci: Basic Appl Res. 2016;27:189-95.

46. Sfenthourakis S, Triantis KA. The Aegean archipelago: a natural laboratory of evolution, ecology and civilizations. J Biol Res-Thessalon. 2017;24:4. https://doi.org/10.1186/s40709-017-0061-3.

47. Hiscock K. Marine nature conservation review: rationale and methods. Joint Nature Conservation Committee, Peterborough, UK; 1996

48. Firth LB, Mieszkowska N, Grant LM, Bush LE, Davies AJ, Frost MT, Moschella PS, Burrow MT, Cunningham PN, Dye SR, Hawkins SJ. Historical comparisons reveal multiple drivers of decadal change of an ecosystem engineer at the range edge. Ecol Evol. 2015;5:3210-22.

49. Vafidis D, Antoniadou C, loannidi V. Population density, size structure, and reproductive cycle of the comestible sea urchin Sphaerechinus granularis (Echinodermata: Echinoidea) in the Pagasitikos Gulf (Aegean Sea). Animals. 2020;10:1506.

50. Underwood AJ. Experiment in ecology. Their logical design and interpretation using analysis of variance. New York: Cambridge University Press; 1997.

51. Gkafas G, Hatziioannou M, Malandrakis EE, Tsigenopoulos CS, Karapanagiotidis IT, Mente E, Vafidis D, Exadactylos A. Heterozygosity fitness correlations and generation interval of the Norway lobster in the Aegean Sea, eastern Mediterranean. J Biol Res-Thessalon. 2019;26:14. https://doi. org/10.1186/s40709-019-0103-0.

52. Vafidis D, Antoniadou C, Kyriakouli K. Reproductive cycle of the edible sea urchin Paracentrotus lividus (Echinodermata: Echinoidae) in the Aegean Sea. Water. 2019:11:1029.

\section{Publisher's Note}

Springer Nature remains neutral with regard to jurisdictional claims in published maps and institutional affiliations.

Ready to submit your research? Choose BMC and benefit from:

- fast, convenient online submission

- thorough peer review by experienced researchers in your field

- rapid publication on acceptance

- support for research data, including large and complex data types

- gold Open Access which fosters wider collaboration and increased citations

- maximum visibility for your research: over $100 \mathrm{M}$ website views per year

At BMC, research is always in progress.

Learn more biomedcentral.com/submissions 